\title{
A Critical Analysis of Pak-US Relations
}

\author{
Zainul Abiden Malik ${ }^{*}, \mathrm{Hu} \mathrm{Bo}^{2}$ \\ ${ }^{I}$ Ph.D. Scholar, School of History and Civilization, Shaanxi Normal University, Xi'an, China \\ ${ }^{2}$ Professor, School of History and Civilization, Shaanxi Normal University, Xi'an, China
}

*Corresponding Author: Zainul Abiden Malik, Ph.D. Scholar, School of History and Civilization, Shaanxi Normal University, Xi'an, China

\begin{abstract}
Pakistan is an important regional player for the United States (USA), as it has helped the US in the war against the Soviet and in the fight against terrorism. No one can disagree the fact that Pakistan depends heavily on US aid. Relations between the two countries are important for a long time.
\end{abstract}

Keywords: Region, War, Interest

\section{INTRODUCTION}

The historical event of September 11, 2001 transformed the future of the world. Shortly, after the shocking incident the Bush administration reveals its war plans for Afghanistan and presented Pakistan with a clear demand to take the side of America or go against it. ${ }^{1}$ The military operation named Operation Enduring Freedom commenced on October 7, 2001. Pakistan reluctantly supported America in the Global War on Terror on three conditions. Firstly, the Northern Alliance, the only militia that had successfully countered the Taliban would not take control of Kabul. Secondly, the United States will help Pakistan in resolving the Kashmir issue. Thirdly, the nuclear assets of Pakistan will remain intact. The US officials at that time assured Pakistan that it will fulfill these demands. But within a few years of Pakistan's decision, the US failed to honor all the three promises. In return of the support Islamabad was rewarded handsomely in the form of aid, diplomatic isolation of the country was ended and debts were reduced, but Pakistan's strategic interests were greatly degraded by the global war on terror. On one side Pakistan received handsome amount of Aid from United States and on the other the large number of influx of Afghan refugees into Pakistan destabilized the economy of Pakistan.

The incidents of 2011 also proved fatal for the countries. The news of controversial killing of Osama Bin Laden by US Naval forces inside the territory of Pakistan came as a shock for whole of the world. Pakistan's credibility suffered a serious blow for not knowing that the most sought after terrorist was present inside its territory and its military and intelligence services come under severe criticism for unable to detect and intercept a foreign military operation inside its territory. The relations further got deteriorated when NATO forces air assault 24 Pakistani soldiers in November 2011. ${ }^{2}$ Resultantly, Pakistan closed its border crossings for the NATO supplies in Afghanistan. These developments lead to fuel bilateral distrust and acrimony on major policies concern are very difficult to resolve because they are related to Pakistan's security issues.

\section{US INTERESTS IN THE REGION}

After the Twin Tower incident, the key objective of US was to root out the militant network in Afghanistan. In the US eyes militant and political Islam was a danger to the western system. ${ }^{2}$ The main importance of US at that time was to defeat terrorism and violent form of political Islam. But the US is now suffering from exhaustion after fighting the longest war in its history. The US is now uncertain in organizing ground troops in Syria. Furthermore, it has also obvious to withdraw its troops from Iraq and Afghanistan due to worsening situation in these states. ${ }^{3}$ Without attaining anything existing it has obvious to end the war in Iraq. One cannot disagree the geographical and geo-strategic construct of Asia Pacific Region. It consists of 20 economies of the world with a total GDP of \$67 trillion. Six of world's top economies are contemporary in this region. China the world's second largest economy is 
participating heavily in the region through its CPEC and OBOR projects. The US wants to control the Asia Pacific Region mostly because of two reasons. Firstly it requirements to control the region through its power in order to counter the rising trend of China in the region. ${ }^{4}$ Secondly, Asia Pacific is rich in natural resources plus US manufacturing industry can decoration significantly in the region. ${ }^{5}$ Because of this reason the US is fraught to make new associations and want to dominate the sea lanes and trade corridors of the region. In US eyes Asia is of high economic and geo-strategic value, but it sees China as a country which poses risk to its interests. So the top most priority of US policy makers is the suppression of China. ${ }^{6}$ As India is seen as rival of China, so the US wants to improve the military, diplomatic and economic stature of India. Moreover, US is instable its focus from Middle East to Asia Pacific through its Pivot to Asia policy in which it is assigning its diplomatic and military resources in Asia Pacific. ${ }^{7}$ Great powers always see new rising powers as a danger to their influence. So for US, rising China and a resurgent Russia pose biggest danger.

For US Pakistan's nuclear program is also a reason of great concern. By placing sanctions on Pakistan, the US tried to prevent Pakistan from obtaining nuclear weapon capability, but failed. ${ }^{17}$ According to some think tanks in order to uphold its effect and presence in the region US wants a divided and unstable South Asia because the US defense and military hardware industry will decoration. While some think tanks are of the opinion that US wants steadiness and peace in the region as it will provide economic chances for US businesses and industry for investment.

The US also wants to uphold its domination in the world by supervisory the natural resources in Middle East and Central Asia. The invasion of Iraq and military placements and bases in the Middle East were a clear proof of this thing. After dreadful defeat in Iraq and Afghanistan, the military bases still exist in the region. ${ }^{8}$

\section{Strategic Interests of PAKISTAN}

Pakistan is continually fronting a Geo-strategic dilemma because of its important location. ${ }^{9}$ Its contribution in the Afghan War and the war on terror has caused in numerous predicaments. Pakistan formed an association with US to attain convinced objectives. Firstly, it wanted to avoid a two front war senior. In its size and economy Pakistan is a small country when associated with India. Because of its aggressive neighborhood, Pakistan needed to sustain friendly relations with the best so that it could help it in times of war. ${ }^{10}$ Pakistan want to have peaceable relations with India, but inappropriately without the resolution of Kashmir dispute this is not possible. Pakistan should also try to pursue and preserve friendly relations with Afghanistan and Iran governments. Pakistan enjoys strong strategic ties with China. China is an all-weather friend of Pakistan both countries have mutual interest in the region. Pakistan depends heavily on Chinese military and economic assistance. China and Pakistan became earlier and supported their defense and economic relations after the end of cold war. ${ }^{11}$ China Pakistan Economic Corridor (CPEC) project is an example of the close relation between the two countries. The aggressive attitude of India, forced Pakistan to pursue nuclear weapons. Kashmir clash between the two countries let to three main wars. Especially, relations between the two countries worsened radically after the division of East Pakistan in $1971 .{ }^{12}$ The nuclear tests of India in 1974 forced Pakistan to seek nuclear weapons. India is continuously modernizing its armed forces which are a big risk to Pakistan's existence .The aggressive attitude of India is the key reason which forced Pakistan to develop close relations with the US and get advantage from the US military technology from time to time. The relationship between US and Pakistan is of transactional nature which retains on varying according to the requirements of US. The 1971 war forced Pakistan to think that nuclear weapons could only assurance its territorial honor in contradiction of a powerful neighbor. Pakistan attained self-sufficiency in the defense industry when US placed sanctions on it. This also occurred that the Pakistani leaders by overlooking the national interest wanted to secure personal relationships with the leaders of US. This resulted in propagating the seeds of antiAmericanism in the masses. All this have caused in miss interest between the Governments of both the countries. ${ }^{13}$ Pakistan with the help of CIA trained and armed some people during the SovietAfghan war but when Pakistan was forced to join the War on Terror after the 9/11 incident, the internal security situation of the country came under serious risk. Terrorism in the country enlarged extremely and defeating the militants and non-state actors become the primary priority of Pakistani Government. Pakistan Foreign policy always remains India centric. ${ }^{14}$ For Pakistan Indian military is an existential danger. Pakistan always required resisting Indian supremacy and Global supremacy. The key impartial of a state is to attain highest level of economic prosperity and development. The 
economic goal of the Government is to project Pakistan's economy as basis of enterprise and innovation .The condition of Pakistan's economy is progressively refining but due to poor governess the External debt is rising.

\section{CONClusion}

This important location of Pakistan will help it in prompting the security, trade and commerce, ideology and social state of its neighboring regions in the coming years. The US-Pakistan relations need a dialogue. Both the countries should redefine their relations and should work together to achieve a larger goal i.e. to root out the threat of terrorism from the region. No one can disagree the fact that Pakistan has always desired peace, stability and prosperity in the region. This was the aim that it always remained practical about peace talks with its neighboring states. Pakistan always wants peace and stability in Afghanistan because stability in Afghanistan is extremely connected to the peace and stability in Pakistan.

\section{REFERENCES}

[1] Zehra, N. (2004, April 8), “Theparadox of Pakistan - US Relations”, The News.

[2] Esposito, John L. "It's the policy, stupid: Political Islam and US foreign policy." Harvard International Review 2 (2007).

[3] Robert D. Kaplan, "Where's the American empire when we need it?",Washington Post, December2010, http://www.washingtonpost.com/wpdyn/content/article/2010/12/03/AR2010120303448.html.

[4] Hillary Clinton, "America's Pacific Century", Foreign Policy, November 2011, http://www.foreignpolicy. com/articles/2011/10/11/americas_pacific_century?page=ful

[5] US News Centre, "Global economy risks falling into renewed recession, warns UN report", December18, 2012,http://www.un.org/apps/news/story.asp?NewsID=43803\#.USxZ4h2j2yY

[6] Ted Galen Carpenter, "Washington's Clumsy China Containment Policy", The

[7] National Interest, November 30, 2011, http://nationalinterest.org/blog/the-skeptics/washington\%E2\% $80 \% 99$ s-clumsy-china-containment-policy-6202

[8] Bush III, Richard C. "The Response of China's Neighbor to the US" Pivot" to Asia." Brookings Institute (2012).

[9] National Security Archive, George Washington University, "Non-Papers and Demarches: US and British Combined to Delay Pakistani Nuclear Weapons Program in 1978-1981, Declassified Documents Show", National Security Archive Electronic Briefing Book No. 352, July 27, 2011, http://www.gwu.edu/ nsarchiv/nukevault/ebb352/index.htm.

[10] Stephen Tanner, Afghanistan: A Military History from Alexander the Great to the Present (Philadelphia: Da Capo Press, 2009), p. 336

[11] Ejaz Haider, "Pakistan Needs Strategic Depth", The Express Tribune, October 7,2011, http://tribune.com.pk/ story/268921/pakistan-needs-strategic-depth/.

[12] Muhammd Ishaque Fani, "Pak-China Security Relations and Mutual Ventures" Journal of the Research Society of Pakistan J.R.S.P, vol.46, no.2, 2009, pp. 83-95.

[13] Hilali, A. Z. US-Pakistan relationship: Soviet invasion of Afghanistan. Taylor \& Francis, 2017.

[14] Hassan Abbas, "How Obama can Fix US-Pakistani Relations", December 21, 2011,Foreign Affairs,https://asiasociety.org/blog/asia/hassan-abbas-how-obama-can-fix-us-pakistani-relations

[15] Woodward, Bob. Obama's wars. Simon and Schuster, 2011.

[16] Javed Husain, "India - an aspiring hegemon", The Nation, February 19, 2013, https://nation.com.pk/19Feb-2013/india-an-aspiring-hegemon

Citation: Zainul Abiden Malik, Hи Bo. "A Critical Analysis of Pak-US Relations". International Journal of Political Science (IJPS), vol5, no.1, 2019, pp.1-3. doi:http://dx.doi.org/10.20431/2454-9452.0501001.

Copyright: () 2019 Authors. This is an open-access article distributed under the terms of the Creative Commons Attribution License, which permits unrestricted use, distribution, and reproduction in any medium, provided the original author and source are credited. 